УДК 351.81

DOI https://doi.org/10.32836/2310-9653-2020-2.36

Г. П. Фердман, кандидат наук з державного управління, старший науковий співробітник, заступник начальника з наукової роботи Науково-дослідного центру Збройних Сил України «Державний океанаріум» Інституту Військово-Морських Сил Національного університету «Одеська морська академія»

\title{
ЗАБЕЗПЕЧЕННЯ БЕЗПЕКИ НА ЗАЛІЗНИЧНОМУ ТРАНСПОРТІ: ДЕРЖАВНО-УПРАВЛІНСЬКИЙ АСПЕКТ
}

Визначено, щзо забезпечення належного рівня управління безпекою залізничного транспорту є одним з основних завдань сучасної держави. Усвідомлюючи його значення для Украӥни, необхідно приділяти більш значну увагу безпеці Укрзалізниці, яка на даний час зостається на недостатньому рівні.

Головним суб'єктом забезпечення транспортної безпеки на залізничному транспорті є Державна служба України з безпеки на транспорті (Укртрансбезпека), щчо є центральним органом виконавчої влади, діяльність якого спрямовується $i$ координується Кабінетом Міністрів Украӥни через Міністра інфраструктури і який реалізує державну політику з питань безпеки на наземному транспорті.

Зазначено, що комплексне управління безпекою руху поїдів, а саме - організаційних $і$ технічних заходів, спрямованих на забезпечення безаварійної роботи та утримання в постійній справності залізничних споруд, колій, рухомого складу, обладнання, механізмів та пристроїв, здійснює Державна адміністрація залізничного транспорту України (Укрзалізниия). Повноваження Укрзалізниці стосовно організації та забезпечення безпеки руху поїздів визначені відповідними документами.

Державний нагляд за безпекою руху поїзів на залізничному транспорті покладається в Міністерстві Інфраструктури України на Головне управління безпеки руху та охорони праці, Державну адміністрацію залізничного транспорту України $i$ їхні органи на місиях: апарат Головних ревізорів з безпеки руху поїзів на залізницях та дирекиіях.

Організацію та забезпечення роботи з безпеки руху поїздів в Міністерстві транспорту та зв 'язку здійснює Управління безпеки в галузі, в Укрзалізниці - Головний ревізор із безпеки руху поїздів і автотранспорту Укрзалізниці (ЦРБ), в Управліннях залізниць - Головний ревізор із безпеки руху поїздів і автотранспорту залізниці (РБ) $і$ в Дирекиіях залізничних перевезень Головний ревізор з безпеки руху поїздів і автотранспорту дирекиії залізничних перевезень (УРБ). У службах та структурних підрозділах залізниць призначаються відповідальні працівники з безпеки руху поїздів. Інші структурні підрозділи Укрзалізниці беруть участь у роботі з питань безпеки руху поїдів згідно з функиіональними обов 'язками.

Ключові слова: транспорт, залізничний транспорт, особливість, аварійність, безпека, державне управління.

\section{G. P. Ferdman. Railway safety: public-management aspects}

It is determined that ensuring the proper level of railway safety management is one of the main tasks of the modern state. Recognizing its importance for Ukraine, it is necessary to pay greater attention to the safety of Ukrzaliznytsia, which remains at present insufficient.

The main subject of railway transport safety is the State Transport Service of Ukraine (Ukrtrans Security), which in turn is the central executive body, whose activity is directed and coordinated by the Cabinet of Ministers of Ukraine through the Minister of Infrastructure and implements state policy on issues safety on land transport.

It is stated that the complex management of train safety, namely - organizational and technical measures aimed at ensuring trouble-free work and keeping the railway facilities, tracks, rolling stock, equipment, mechanisms and devices in good working order, is carried out by the State Railway Administration of Ukraine (Ukrzaliznytsia). Ukrzaliznytsia's authority to organize and ensure train safety is set out in the relevant documents.

The State Supervision of Train Safety on Rail Transport is assigned by the Ministry of Infrastructure of Ukraine to the Main Directorate of Traffic Safety and Labor Protection, State Administration of Railway Transport of Ukraine and their bodies on the ground: apparatus of the Chief Examiners for Train Traffic on Railways and Directorates.

The structural and functional scheme of train safety management at Ukrzaliznytsia is based on the principle of systematic operation in covering all levels of control.

Organization and provision of work on train safety in the Ministry of Transport and Communications is carried out by the Department of Safety in the industry, in Ukrzaliznytsia - the Chief Auditor of train and motor transport of Ukrzaliznytsia (CRB), in the Railway Departments - the Chief Auditor of Train and Motor Transport (RB) and in the Railway Directorates - the Chief Auditor of Train Safety and Road Transport (URB). Railway safety departments and units are responsible for train safety. Other structural units of Ukrzaliznytsia are involved in the work on train safety in accordance with their functional responsibilities.

The internal and external factors of Ukrzaliznytsia management are considered.

Railway undertakings are obliged to ensure the safety and security of citizens, the safety of the operation of vehicles, and the protection of the environment.

Key words: transport, railway, feature, accident, safety, public administration. 
Постановка проблеми. Залізничний транспорт (залізниця) - вид рейкового транспорту, що здійснює перевезення пасажирів та вантажів в колісних екіпажах, що рухаються залізничною колією. Залізничний транспорт $\epsilon$ галуззю промисловості, частиною транспортної мережі логістичних ланцюгів, які сприяють міжнародній торгівлі і економічному зростанню.

Залізничний транспорт України є складовою частиною системи транспорту України. Він виконує важливі функції у зв'язках України з іншими державами і регіонами світу та займає важливе місце у транспортній системі країні, грає значну роль у забезпеченні міжнародних транспортних зв'язків.

Наведемо основні показники залізничного транспорту України (крім тимчасово окупованої території Автономної республіки Крим і м. Севастополь, а також частини зони проведення ООС): експлуатаційна довжина головних колій - 19787 км, електрофікованих колій - 9319 км, ширина колії - 1520 мм; кількість залізничних станцій - 1402 од.; кількість залізних переїздів - 105 од.; кількість переїздів головних і станційних - 4198 од.; інвентарний парк вантажних вагонів - 85, 2 тис. од.; інвентарний парк пасажирських вагонів - 4,32 тис. од.; інвентарний парк тепловозів - 1944 од.; інвентарний парк електровозів - 1627 од.; інвентарний парк дизель-поїздів 301 секція; середня кількість працівників - 266, 3 тис. осіб; відправлено пасажирів за 2019 рік - 149, 6 млн. пас.; відправлено вантажів за 2019 рік - 312,4 млн. тон. [1, с. 1].

Не зважаючи на вищезазначене, проблеми транспортної безпеки за останні роки стали ще гостріше, оскільки транспорт фактично перетворився на одну з найризикованіших сфер життєдіяльності, в якій, на жаль, регулярно гинуть люди. Згідно з інформацією, яка надходила до Укртрансбезпеки, у 2019 році на залізничному транспорті України сталось 1202 транспортні події, з них: 705 аварій, в яких 354 особи загинули та 232 отримали травми, 3 них: 1) 577 аварії зі сторонніми особами завдані рухомим складом залізничного транспорту, в яких 354 особи загинули та 232 отримали травми; 2) 128 аварій за участю залізничного транспорту, без постраждалих. 3) 473 інциденти, без постраждалих; 4) 24 пожежі. Протягом 2019 року на залізничних переїздах Укрзалізниці сталось 65 дорожньо-транспортних пригод, в яких 11 осіб загинули та 20 отримали травми [2, с. 14].

Отже, забезпечення належного рівня управління безпекою залізничного транспорту є одним 3 основних завдань сучасної держави. Усвідомлюючи його значення для України, необхідно приділяти більш значну увагу безпеці Укрзалізниці, яка на даний час зостається на недостатньому рівні.

Аналіз останніх досліджень і публікацій. Важливе значення для дослідження проблеми транспортної безпеки та державного управління транспортними системами мають наукові праці В.Ф. Андресюка, Л.М. Артюшина, А. С. Гальчинського, Б. Гурне, Ж. Зітера, О.С. Ігнатенка, В.В. Лісничого, О.М. Ложачевської, Г.І. Міщенка, В.Ф. Опришка, М.В. Онищука, І.М. Пахомова, Ю.С. Пащенка, В.Й. Развадовського, В.М. Рижих, А.Г. Савченка, А.І. Семенченка, В.А. Скуратівського, Д.А. Тимохи, А.М. Ткаченко, В.В. Юрчишина. та ін. Разом із тим окремі питання в цій сфері потребують подальшого обговорення та вдосконалення.

Мета статті полягає в короткому висвітленні: особливої ролі залізничного транспорту в єдиній транспортній системі України та його складу та особливостей із деякими статистичними даними перевезень та аварійності за 2019 рік; ієрархічної «вертикальної» структури забезпечення безпеки на залізничному транспорті; організаційно-правових основ державного управління безпекою на залізничному транспорті України, внутрішніх та зовнішніх факторів управління Укрзалізницею з відповідними висновками.

Виклад основного матеріалу. Головним суб'єктом забезпечення транспортної безпеки на залізничному транспорті є Державна служба України з безпеки на транспорті (Укртрансбезпека), що є центральним органом виконавчої влади, діяльність якого спрямовується і координується Кабінетом Міністрів України через Міністра інфраструктури і який реалізує державну політику з питань безпеки на наземному транспорті.

Основними завданнями Укртрансбезпеки стосовно залізничного транспорту є: реалізація державної політики з питань безпеки на залізничному транспорті; внесення на розгляд Міністра інфраструктури пропозицій щодо забезпечення формування державної політики з питань безпеки на залізничному транспорті; здійснення державного нагляду (контролю) за безпекою на залізничному транспорті; надання в передбачених законом випадках адміністративних послуг у сфері залізничного транспорту [3, ст. 4].

Слід відзначити, що Укртрансбезпека під час виконання покладених на неї завдань взаємодіє 3 іншими державними органами, допоміжними органами і службами, утвореними Президентом України, тимчасовими консультативними, дорадчими та іншими допоміжними органами, утвореними Кабінетом Міністрів України, органами місцевого самоврядування, об'єднаннями громадян, громадськими спілками, профспілками та організаціями роботодавців, відповідними органами іноземних держав і міжнародних організацій, а також підприємствами, установами та організаціями.

Комплексне управління безпекою руху поїздів, а саме - організаційних і технічних заходів, спрямованих на забезпечення безаварійної роботи та утримання в постійній справності залізничних споруд, колій, рухомого складу, обладнання, механізмів та пристроїв, здійснює Державна адміністрація залізничного транспорту України (Укрзалізниця). 
На кожному рівні управління організаційної структури Укрзалізниці реалізують завдання управління безпекою руху поїздів із використанням типових елементів управлінського циклу (планування, організація, оперативне керівництво й координація, контроль, облік, аналіз та оцінка).

До функцій управління безпекою руху поїздів належать: організація та координація робіт; інформаційно-аналітичне забезпечення; оперативне реагування та розслідування транспортних подій; планування та виконання робіт із безпеки руху; спеціальні функції; пропаганда безпеки руху; контрольні функції та управлінські рішення [4, ст. 2.4].

Повноваження Укрзалізниці стосовно організації та забезпечення безпеки руху поїздів визначені ст. 16 Закону України «Про транспорт» (п. 2.2), ст. 11 Закону України «Про залізничний транспорт» (п. 2.3), Статутом залізниць України (п. 2.19) та Правилами технічної експлуатації (ПТЕ) (п. 2.25)

Система управління безпекою руху поїздів (СУБРП) - структурована та документована система, що надає можливість персоналу Укрзалізниці, залізниць, підприємств та структурних підрозділів ефективно проводити політику у сфері забезпечення безпеки руху поїздів, $є$ цільовою підсистемою загальної системи управління в Укрзалізниці. Під час організації і функціонування процесу перевезень забезпечує підготовку, прийняття та реалізацію організаційних, управлінських та технічних рішень, спрямованих на убезпечення руху поїздів, збереження життя і здоров'я людей, майна, довкілля та виявлення й оцінку чинників, що впливають на рівень безпеки.

Залізниці та інші підприємства Укрзалізниці на основі Положення про Систему управління безпекою руху поїздів у Державній адміністрації залізничного транспорту України розробляють Положення про систему управління безпекою руху поїздів на підприємстві.

Основними принципами в організації роботи з управління безпекою руху поїздів є: системність, що передбачає системний, постійний та упорядкований характер діяльності всіх складових частин системи; випередження спрямований на своєчасне виявлення та усунення негативних факторів, що можуть призвести до транспортних подій; колективізм, який передбачає участь усіх працівників у роботі із забезпечення безпеки руху, згідно зі своїми функціональними обов'язками, а не тільки керівників і працівників служби безпеки руху; інформованість, що будується на максимальній інформованості кожного працівника про небезпечні фактори, які впливають на рівень безпеки руху; виявлення та усунення причин, що передбачає проведення профілактичної роботи, спрямованої не тільки на покарання винних, скільки на усунення виявлених недоліків; упровадження коригувальних дій: дія, яку виконують для усунення причин виявленої невідповідності або для іншої небажаної ситуації; упровадження запобіжних дій для усунення причин потенційної невідповідності або іншої потенційно небажаної ситуації; адекватність - відповідність заходів із забезпечення безпеки руху реальним та потенційним загрозам; відповідальність передбачає усвідомленість кожного працівника та його відповідальність на своєму робочому місці за конкретні питання, що визначають безпеку руху поїздів.

Аналізуючи систему управління безпекою руху поїздів, особливу увагу слід надати розміщенню об’єктів, пов'язаних із виробництвом, зберіганням, навантаженням, транспортуванням і розвантаженням вибухових, легкозаймистих, радіоактивних речовин та матеріалів, отруйних і сильнодіючих хімічних речовин, що визначається відповідними будівельними та санітарними нормами і правилами стосовно об'єктів, розташованих на землях залізничного транспорту загального користування. Місця перетину залізничних колій трубопроводами, лініями зв'язку та електропередач, іншими комунікаціями повинні погоджуватися з Укрзалізницею.

Державний нагляд за безпекою руху поїздів на залізничному транспорті покладається в Міністерстві Інфраструктури України на Головне управління безпеки руху та охорони праці, Державну адміністрацію залізничного транспорту України і їхні органи на місцях: апарат Головних ревізорів з безпеки руху поїздів на залізницях та дирекціях.

Будь-які складні державні структури мають ієрархічну структуру - «вертикальну» диференціацію функцій між різними рівнями управління, такими як система посад, звань, чинів, що розміщенні в послідовності підлеглості - від нижчих до вищих. У них виділені рівні (елементи), наділені певними правами та обов'язками щодо інших, правом розпоряджатися ресурсами, призначати цілі, стягнення або заохочення окремих людей і цілих колективів. Виникнення ієрархічної організованості - це внутрішня потреба систем, одна з важливих передумов підвищення їі стабільності, ефективності функціонування.

Структура має 4 рівні: міністерство, Укрзалізниця, дорога - регіон, лінійні підприємства. Організацією і контролем безпеки руху на дорозі займається апарат з безпеки руху поїздів і автотранспорту. Для додання більшого значення і ваги унаслідок важливості цей підрозділ в управлінні одержав назву «апарат», а не «служба», а керівник апарату - дорожній ревізор - $є$ заступником начальника залізниці, якому підпорядковуються 3 даних питань усі начальники служб та інші заступники начальника залізниці.

Структура безпеки руху носить галузевий характер. Безпека $є$ найважливішим принципом і змістом роботи галузевих оперативних служб і підлеглих їм лінійних підприємств. 3 іншого боку, в апараті з безпеки є ревізори, які контролюють та організують цю діяльність по службах. Те ж саме відноситься і до ревізорських дільниць у регіонах. У штаті служб існують посади ревізорів, що підпорядковуються начальникам відповідних служб, а не 
дорожньому ревізорові. У різних службах це організовано по-різному. У службі перевезень є ревізорські дільниці, у службі комерційної роботи та маркетингу - напрямки. Ревізорські дільниці в регіонах здійснюють контроль і організацію безпеки безпосередньо в лінійних підприємствах і теж за галузевим принципом.

Щодо структурно-функціональної схеми управління безпекою руху поїздів в Укрзалізниці, то вона побудована за принципом системності в роботі з охопленням усіх рівнів управління.

Управління здійснюється шляхом цілеспрямованого регулювання організаційних, технічних, психофізіологічних факторів, що впливають на безпеку руху поїздів. Органами управління є: Укрзалізниця, залізниці, дирекції залізничних перевезень, об'єднання, підприємства та структурні підрозділи, що мають право приймати управлінські рішення в межах своєї компетенції та стежити за виконанням прийнятих рішень; суб'єктами управління персонал, функціональні служби, структурні підрозділи, спеціально створені органи, які впливають на систему управління безпекою руху поїздів із метою забезпечення ії функціонування; об'єктами управління - стан безпеки технологічних процесів, транспортних засобів, залізничної колії, устаткування, споруд, пристроїв, інших об’єктів транспорту, персоналу.

Інформація про виявлені відхилення від вимог безпеки руху та транспортні події надходить в органи управління для аналізу, розслідування, прийняття управлінських рішень та контролю за їх виконанням.

Управління безпекою руху поїздів здійснюється шляхом постійного цілеспрямованого виявлення негативних факторів, їх аналізу, розроблення додаткових керуючих дій, їх реалізації та контролю за виконанням.

Функціонування системи управління безпекою руху поїздів передбачає формування органів управління, установлення функціональних обов'язків для структурних підрозділів та посадових осіб, що беруть участь в управлінні, а також регламентацію їхньої діяльності.

Організацію та забезпечення роботи з безпеки руху поїздів в Міністерстві транспорту та зв'язку здійснює Управління безпеки в галузі. В Укрзалізниці - Головний ревізор із безпеки руху поїздів і автотранспорту Укрзалізниці (ЦРБ), в Управліннях залізниць - Головний ревізор із безпеки руху поїздів і автотранспорту залізниці (РБ) і в Дирекціях залізничних перевезень - Головний ревізор із безпеки руху поїздів і автотранспорту дирекції залізничних перевезень (УРБ). У службах та структурних підрозділах залізниць призначаються відповідальні працівники з безпеки руху поїздів. Інші структурні підрозділи Укрзалізниці беруть участь у роботі з питань безпеки руху поїздів згідно з функціональними обов'язками.

Головним завданням системи управління безпекою руху поїздів є систематизація роботи з безпеки руху, що проводиться в Укрзалізниці, підвищення іiі ефективності та цілеспрямованості шляхом раціонального й планомірного використання всіх організаційних, економічних та технічних можливостей Укрзалізниці.

Вище було розглянуто внутрішні фактори управління Укрзалізницею, щодо зовнішніх механізмів взаємодії з іншими організаціями, то підприємства залізничного транспорту співпрацюють у тісній взаємодії з іншими державними структурами. Наприклад, транспортні засоби, споруди, устаткування транспорту можуть перебувати у власності підприємств, об'єднань, установ, організацій і громадян. Щодо загальнодержавної власності, то тут також перебувають транспортні засоби, споруди, устаткування транспорту, але ті, що закріплені за підприємствами, об'єднаннями, установами та організаціями інших міністерств і відомств (відомчий транспорт).

Підприємства залізничного транспорту забезпечують збереження вантажів та багажу із часу їх прийняття для перевезення і до видачі їх одержувачам, якщо інше не передбачено договором. Перелік вантажів, що підлягають спеціальній охороні та супроводу, затверджується Кабінетом Міністрів України. Порядок охорони та супроводу таких вантажі встановлюється Міністерством транспорту України.

Перелік військових вантажів, порядок охорони і супроводу їх караулами встановлюються Міністерством оборони України за погодженням з Міністерством Інфраструктури України.

Охорона та супровід небезпечних і цінних вантажів за переліком, затвердженим Кабінетом Міністрів України, забезпечуються відправниками або одержувачами вантажів протягом усього шляху руху.

Порядок охорони та супроводу вантажів, що швидко псуються, визначається відправниками (одержувачами) вантажів самостійно і погоджується з Міністерством транспорту України.

Охорона громадського порядку, забезпечення особистої безпеки громадян, захист їхніх прав, свобод і законних інтересів, запобігання правопорушенням та їх припинення, виявлення і розкриття злочинів, розшук осіб, які їх вчинили, захист власності від злочинних посягань, державний пожежний нагляд на транспорті забезпечуються органами Міністерства внутрішніх справ України за сприяння підприємств транспорту.

Підприємства залізничного транспорту зобов'язані забезпечувати безпеку життя і здоров'я громадян, безпеку експлуатації транспортних засобів, охорону навколишнього природного середовища.

Нагляд за забезпеченням безпеки руху транспортних засобів здійснюється в порядку, встановленому Кабінетом Міністрів України.

Таким чином, з урахуванням вищенаведеного можливо зробити такі висновки:

1. Забезпечення належного рівня транспортної безпеки України є одним з основних завдань сучасної держави, іiі стан порівняно з розвиненими країнами світу є незадовільним, тому їй поки що приділяється недостатня увага. 
2. Державне управління у сфері безпеки залізничного транспорту здійснює Державна служба України з безпеки на транспорті (Укртрансбезпека), яка $є$ центральним органом виконавчої влади, діяльність якого спрямовується і координується Кабінетом Міністрів України через Міністра Інфраструктури, що реалізує державну політику з питань безпеки на наземному транспорті;

3. Залізничний транспорт забезпечує свою безпеку, для чого існують відповідні керівні документи, сили та засоби.

4. Водночас із вищезазначеним бачимо відсутність загального керівництва транспортною безпекою України та взаємодії залізничного транспорту з іншими видами транспорту у сфері транспортної безпеки, яка б була оформлена відповідними документами.

Перспективи подальших розвідок у даному напрямку вважаємо дослідження переходу на європейські стандарти транспортної безпеки на всіх видах транспорту в Україні.

\section{Список використаних джерел:}

1. Статистичні дані про Українські залізниці URL : https://mtu.gov.ua/content/statistichni-dani-pro-ukrainskizaliznici.html (дата: звернення 19.04.20).

2. Публічний звіт Голови Державної служби України з безпеки на транспорті Олександра Погорілого за 2019 рік URL : https://www.kmu.gov.ua/storage/app/sites/1/17-civik-2018/zvit_2019/zvit-2019-ukrtransbezpeka.pdf (дата звернення: 19.04.20).

3. Постанова Кабінету Міністрів України від 11 лютого 2015 р. № 103 (із змінами) «Про затвердження Положення про Державну службу України з безпеки на транспорті» URL : https://zakon.rada.gov.ua/laws/show/103-2015$\% \mathrm{D} 0 \% \mathrm{BF}$ (дата звернення: 19.04.20).

4. Наказ Міністерства Інфраструктури України від 01.04.2011 № 27 «Про затвердження Положення про систему управління безпекою руху поїздів в Державній адміністрації залізничного транспорту України». URL : https://zakon.rada.gov.ua/laws/show/z0729-11 (дата звернення 19.04.20).

\section{References:}

1. Statystychni dani pro Ukrainski zaliznytsi URL: https://mtu.gov.ua/content/statistichni-dani-pro-ukrainskizaliznici.html (data zvernennia 19.04.20).

2. Publichnyi zvit Holovy Derzhavnoi sluzhby Ukrainy z bezpeky na transporti Oleksandra Pohoriloho za 2019 rik URL: https://www.kmu.gov.ua/storage/app/sites/1/17-civik-2018/zvit_2019/zvit-2019-ukrtransbezpeka.pdf (data zvernennia 19.04.20).

3. Postanova Kabinetu Ministriv Ukrainy vid 11 liutoho 2015 r. № 103 (iz zminamy) «Pro zatverdzhennia Polozhennia pro Derzhavnu sluzhbu Ukrainy z bezpeky na transporti» URL: https://zakon.rada.gov.ua/laws/show/1032015-\%D0\%BF (data zvernennia 19.04.20).

4. Nakaz Ministerstva Infrastruktury Ukrainy vid 01.04.2011 № 27 «Pro zatverdzhennia Polozhennia pro systemu upravlinnia bezpekoiu rukhu poizdiv v Derzhavnii administratsii zaliznychnoho transportu Ukrainy» URL: https://zakon.rada.gov.ua/laws/show/z0729-11 (data zvernennia 19.04.20). 